\title{
Capsule Dosing Unit
}

National Cancer Institute

\section{Source}

National Cancer Institute. Capsule Dosing Unit. NCI Thesaurus. Code C48480.

A dosing unit equal to the amount of active ing redient(s) contained in a capsule. 